\title{
Analysis of Supplier Selection of Plate Raw Material (Case Study: PT XYZ)
}

\author{
Dewie Saktia Ardiantono ${ }^{1}$, Bustanul Arifin Noer ${ }^{1}$, Dhea Elvira Rosa ${ }^{1}$, M. Ubaidillah Al Mustofa ${ }^{2}$ \\ ${ }^{1}$ Departement of Business Management, Faculty of Business and Technology Management, Institut Teknologi \\ Sepuluh Nopember. Surabaya, 60111, E-mail: dewie@ mb.its.ac.id \\ ${ }^{2}$ Department of Islamic Economics, Faculty of Economic and Business, Universitas Airlangga, Surabaya, \\ 60285, E-mail: ubaid9339902@gmail.com
}

\author{
Diterima: 08/08/2019 \\ Direview: 19/10/2019 \\ Diterbitkan: 28/11/2019 \\ Hak Cipta @ 2019 oleh Penulis (dkk) dan Jurnal \\ Sosial Humaniora (JSH) \\ *This work is licensed under the Creative \\ Commons Attribution International License (CC \\ BY 4.0). \\ http://creativecommons.org/licenses/by/4.0/ \\ Open Access
}

\begin{abstract}
Subject Area: Economy (Ekonomi)
Abstract - PT. XYZ is one of the State-Owned Enterprises of Strategic Industries (BUMNIS) which runs the business field of Project Management and Services (MPJ) and Machinery and Equipment Industry (MPI). Currently the company is experiencing problems of not achieving the sales growth target in 2012-2016. This problem is caused mainly by one of the problems in supply chain, namely the delay of raw materials on the project undertaken. From the results of previous study, it was found that supplier selection evaluation has the highest value of the total effectiveness to difficulty ratio (ETDk); therefore, evaluation on supplier selection should be done in order to establish good integration. The method used is Analytical Hierarchy Process. Criteria that have been determined is the price, delivery, quality, and service. As a result, the sub criteria of price and quality compliance has the highest value and the first supplier is the best supplier.
\end{abstract}

Keywords: Analytical Hierarchy Process; Supply Chain; Supplier Selection

\section{Introduction}

In general supply chain, risks may arise in a variety of incident, one of which is a delay of material. Supply chain management in PT XYZ is also become a challenge since it involves the whole company and the external that is associated with the activities of business process.

Procurement is an important part in the supply chain of PT XYZ. There are activities to fulfill or supply the needs and supply of goods. In these fulfillment activities, supplier selection plays an important role. The selection of raw material suppliers is one of the activities in supply chain management at PT XYZ. This activity is categorized as a strategic activity, because the role of the supplier will take part in determining the accuracy of certain project works. If the supplier cannot provide the raw materials according to the company's requirements, then it is certain that the production schedule will also be disrupted.

In Project $\mathrm{X}$, the main material that become the majority of tank construction is the plate. For this reason, this research will focus on selecting suppliers for plate raw materials. The plate raw material selected in this study is the plate that has the highest quantity in the project, namely as many as three plate materials. In this project, there are four potential suppliers to supply the required plate material

Previous research that forms the basis of this research regarding supplier selection using the AHP (Analytical Hirearchy Process) method. Koç and Burhan (2014) mentioned that the AHP method can be used 
to analyze quantitative and qualitative criteria to choose the best supplier. Supplier selection research using the AHP method has also been carried out by Dweiriet (2016). This research was conducted at an automotive company in Pakistan.

Based on the previous research, companies need to consider many criteria for selecting suppliers, both qualitative and quantitative criteria. In selecting suppliers, there are various criteria that are considered by PT XYZ in selecting appropriate suppliers. The criteria chosen by PT XYZ are price, delivery, quality and service. Hence, in this study the researcher will evaluate the best suppliers of plate raw material that meets the supplier selection criteria at PT XYZ.

\section{Literature Review}

\section{Supply Chain Management}

Supply Chain Management (SCM) is an approach for efficient integration between suppliers, factories, distribution centers, wholesalers, retailers and end customers, where products are produced and distributed in the right amount, the right location and the right time in order to minimize system costs and improve service level. (Putri, 2012).

\section{Supplier Selection}

In the supply chain concept, the supplier is one of the most important supply chain parts and influences the continuity of supply chain activities in a company, where the supplier becomes an important party that supplies raw materials for the company. If the supplier is less responsible in responding to the fulfillment of the demand for factory raw materials, it will cause serious problems such as stockout or lead time which will certainly harm the company. Hence, the company that has many suppliers must be selective in choosing their suppliers (Suciadi, 2013).

Supplier selection has five stages starting from the realization of the need for new suppliers, the determination and formulation of decision criteria, prequalification, selection of final suppliers, and monitoring of supplier selection. According to Mwikali and Kavale (2012) the selection of supplier criteria starts from:

1. Evaluate, evaluate and identify characteristics of potential suppliers

2. Evaluation to measure supplier conformity.

3. Establish weights of each criterion to identify supplier ratings.

4. Sub-criteria assessment.

5.Evaluate potential suppliers of the characteristics that have been identified and are given a weighting rating.

Suppliers are chosen through a complex process by considering many criteria. This is due to supplier performance criteria that seek to meet all the desires of the industry, such as in the selection of traditional suppliers that consider several criteria such as cost, delivery time, quality, and service (Amer et al., 2009).

\section{AHP (Analytical Hierarchy Process)}

Analytical Hierarchical Process (AHP) is one of the widely accepted MCDM approaches which are 
accepted by researchers because of its nature to make optimal and best decisions (Singh, 2016). This method is one of the multicriteria decision making models that helps human thinking framework where the factors of logic, experience, knowledge, emotions, and taste are optimized into a systematic process.

\section{Research Method}

The following are steps to apply the AHP evaluation model in selecting suppliers:

1. Determine the criteria and sub-criteria

The first step that will be taken is to determine the criteria and sub-criteria. These criteria and subcriteria serve as a benchmark for all suppliers who become suppliers of raw material for plate material in Project X. There are four criteria considered in selecting the best supplier in Project X, namely price, delivery, quality and service. There are eight sub-criteria that follow these four criteria.

2. Determine the suppliers to be evaluated

The suppliers evaluated are local suppliers who supply plate material to Project X. There are four prospective suppliers who have passed the selection process. These suppliers are Supplier 1, Supplier 2, Supplier 3 and Supplier 4 which the researcher did not mention at the request of the Procurement Division of PT XYZ.

3. Determine the hierarchical structure of supplier selection

The use of AHP method in this study is divided into 4 levels. The top level is the goal of choosing the best supplier. Below the level of the second level is a criterion level consisting of price, shipping, quality and service specification criteria. The third level is broken down again into a list of sub-criteria that follow predetermined criteria. The lowest level is the alternative supplier level, which is occupied by four suppliers of Project X plates.

4. Determination of interests

AHP is used to determine the relative weights of each criterion, sub-criteria and alternative suppliers. The relative weights of the suppliers' criteria, sub-criteria and alternatives are determined using pairwise comparisons.

5. Consistency Ratio

Consistency ratio shows an opinion has a value that is in accordance with the grouping of elements in the hierarchy or in other words the level of consistency shows the level of accuracy of an opinion on elements at a level of the hierarchy

6. Evaluate the best suppliers' criteria, sub-criteria and alternatives.

The results of the criteria and sub Criteria weights will be calculated to determine the best supplier. The highest weight value of the criteria and sub-criteria is indicated as the criteria most considered by the company in selecting suppliers. High weight values for each alternative supplier will provide high services as well. Suppliers who have the highest total priority value are indicated as the best suppliers.

\section{Result and Discussion}

Data for measuring the priority of interests of the criteria in supplier selection was obtained through a questionnaire distributed to 7 respondents from the Director of Operations and Marketing which was 
divided into several divisions and academician from reputable university. Those respondents are General Manager of Procurement, Manager of Procurement, Head of Service Procurement, Head of Product Procurement, Staff of Purchasing, Staff of Document Controlling, and Lecturer of Business Management.

From the results of pairwise comparison AHP calculation between variables in selecting suppliers above obtained the weights shown in Table 1 below:

Table 1. Priority of Interest Weight Criteria in Supplier Selection

\begin{tabular}{rcc} 
Criteria & Weight & Priority \\
\hline Price & 0,336 & I \\
Quality & 0,228 & III \\
Service & 0,172 & IV \\
Delivery & 0,264 & II \\
\hline
\end{tabular}

The following is the result of AHP processing from the calculation of the weight or priority of interests of each variable in the sub-criteria:

\section{Price}

Table 2 shows that in the two sub-criteria that exist on price, the suitability of price and quality has a higher weight than the suitability of price and payment flexibility.

Table 2. Results of Calculation of Price Sub-Criteria Priority

\begin{tabular}{lcc}
\hline \multicolumn{1}{c}{ Sub Criteria } & Weight & Priority \\
\hline Suitability of price and quality (P1) & 0,812 & I \\
Suitability of price and payment & 0,188 & II \\
flexibility (P2) & & \\
\hline
\end{tabular}

\section{Delivery}

Table 3 shows that in the two sub-criteria that exist in the delivery, the suitability of the shipment and the time delivery have a weight higher than the suitability of delivery and the accuracy of the number of deliveries.

Table 3. Results of Calculation of Shipping Sub-Criteria Priority

\begin{tabular}{lcc}
\hline \multicolumn{1}{c}{ Sub Criteria } & Weight & Priority \\
\hline $\begin{array}{l}\text { Suitability of the shipment and the } \\
\text { time delivery (D1) }\end{array}$ & 0,763 & I \\
Suitability of delivery and the accuracy of the & 0,237 & II \\
number of deliveries & & \\
(D2) & & \\
\end{tabular}

\section{Quality}

Table 4 shows that in the two sub-criteria that exist on quality, the suitability of quality with specifications has a higher weight than the suitability of quality and supply of goods without defects. 
Table 4. Results of Quality Sub-Criteria Priority Calculation

\begin{tabular}{lccc}
\hline \multicolumn{1}{c}{ Sub Criteria } & Weight & Priority \\
\hline $\begin{array}{l}\text { Suitability of quality with } \\
\text { specifications (Q1) }\end{array}$ & 0,851 & I \\
Suitability of quality and supply of goods & 0,149 & II \\
without defects (Q2) & & \\
\hline
\end{tabular}

\section{Service}

Table 5 it shows that in the two sub-criteria that exist in the service, the suitability of the service with guarantee and complaint service have a higher weight than the suitability of the service and the speed of responding to requests.

Table 5. Results of Service Sub-Criteria Priority Calculation

\begin{tabular}{lcc}
\hline \multicolumn{1}{c}{ Sub Criteria } & Weight & Priority \\
\hline $\begin{array}{l}\text { Suitability of the service with } \\
\text { guarantee and complaint service (S1) }\end{array}$ & 0,565 & I \\
$\begin{array}{l}\text { Suitability of the service and the speed of } \\
\text { responding to requests (S2) }\end{array}$ & 0,435 & II \\
\end{tabular}

After the global priority is obtained, the weight of each alternative can be calculated by adding up the overall weight (global priority) for each Supplier, the results are shown in Table 6.

Table 6. Result of Alternative Supplier from AHP

\begin{tabular}{ccc}
\hline Supplier Alternatives & Weight & Priority \\
\hline Supplier 1 & 0,300 & I \\
Supplier 2 & 0,276 & II \\
Supplier 3 & 0,253 & III \\
Supplier 4 & 0,170 & III \\
\hline
\end{tabular}

Table 6 shows that overall, Supplier 1 with a weight value of 0.300 is the priority to be chosen as a supplier of plates for PT XYZ in Project X. The second priority is the second Supplier with a weight value of 0.276 . The third priority is the third Supplier with a weight value of 0.253 . For the last priority is Supplier 4, with a weight value of 0.170. Supplier selection if based on each criterion can be seen in Table 7.

Table 7. Weight of Alternative Supplier Rank for Each Criteria

\begin{tabular}{ccccc}
\hline Criteria & Supplier 1 & Supplier 2 & Supplier 3 & Supplier 4 \\
\hline Price & $\mathbf{0 , 5 9 1}$ & 0,570 & 0,528 & 0,311
\end{tabular}




$\begin{array}{ccccc}\text { Quality } & 0,536 & 0,468 & \mathbf{0 , 5 8 9} & 0,406 \\ \text { Service } & 0,554 & 0,465 & \mathbf{0 , 5 6 4} & 0,417 \\ \text { Delivery } & 0,571 & 0,427 & \mathbf{0 , 6 2 0} & 0,381\end{array}$

Table 7 shows that Supplier 1 is superior to the criteria, namely price criteria with a weight of 0.591 . Supplier 3 excels at shipping criteria with a weight of 0.589 , quality criteria with a weight of 0.564 , and service criteria with a weight of 0.620 . Whereas Suppliers 2 and 4 do not have the highest value in the four criteria.

\section{Conclusion}

There are four criteria prioritized, namely price, shipping, price and service. Price criterion has the highest weight value in the selection criteria for PT XYZ plate raw material suppliers in project X. Sub-criteria P1, which is the suitability of price and quality, has the highest weight value of all sub- criteria. Supplier 1 excels in all priority price, delivery, price and service criteria in selecting Supplier X project with a global value of 0,300 .

\section{Bibliography}

Amer, Y., Luong, L., dan Lee, S., (2009), Optimizing Order Fulfillment in A Global Retail Supply Chain, University of South Australia, Australia.

Dweiri, Fikri (2016). Designing An Integrated AHP Based Decision Support System For Supplier Selection In Automotive Industry. Expert Systems with Applications 62 (2016) 273-283

Koç, Eylem \& Burhan, Hasan Arda. (2014). An Analytic Hierarchy Process (AHP) Approach to a Real World Supplier Selection Problem: A Case Study of Carglass Turkey. Global Business and Management Research: An International Journal Vol.6, No.1

Mwikali, Ruth and Kavale, Stanley. (2012). Factors Affecting the Selection of Optimal Suppliers in Procurement Management. International Journal of Humanities and Social Science Vol. 2 No. 14

Putri, C.F. (2012). Pemilihan Supplier Bahan Baku Kertas Dengan Model QCDFR dan Analytical Hierarchy Process (AHP). Jurnal Widya Teknika.Vol. 20.No. 20, Oktober 2012. Hal 32-38.

Singh, Brijendra. (2016). Analytical hierarchical process (AHP) and fuzzy AHP applications - A review paper. Int. J. Pharm. Technol. 8(4), 4925-4946

Suciadi, Y. (2013). Pemilihan dan Evaluasi Supplier pada PT. New Hope Jawa Timur dengan Menggunakan Metode Fuzzy Analytical Hierarchy Process. Jurnal Ilmiah Mahasiswa Universitas Surabaya. 2(1), $1-17$. 